The Hedging Efficiency of Crude Oil Markets

\author{
P Horsnell, A Brindle \& W Greaves
}

Oxford Institute for Energy Studies

WPM 20

February 1995 


\section{THE HEDGING EFFICIENCY}

OF CRUDE OIL MARKETS

Paul Horsnell

Alban Brindle

Walter Greaves

WPM 20

Oxford Institute For Energy Studies

February 1995 
The contents of this paper are the authors' sole responsibility. They do not necessarily represent the views of the Oxford Institute for Energy Studies or any of its Members.

\title{
Copyright ${ }^{\oplus} 1995$
}

\section{Oxford Institute for Energy Studies}

\begin{abstract}
All rights reserved. No part of this publication may be reproduced, stored in a retrieval system, or transmitted in any form or by any means, electronic, mechanical, photocopying, recording, or otherwise, without prior permission of the Oxford Institute for Energy Studies.

This publication is sold subject to the condition that it shall not, by way of trade or otherwise, be lent, resold, hired out, or otherwise circulated without the publisher's prior consent in any form of binding or cover other than that in which it is published and without a similar condition including this condition being imposed on the subsequent purchaser.
\end{abstract}

ISBN 0948061863 


\title{
The Hedging Efficiency of Crude Oil Markets
}

\author{
Paul Horsnell, Alban Brindle and Walter Greaves
}

\begin{abstract}
This paper considers the measurement of hedging efficiency. It is argued that conventional measures of the efficiency of risk management operations may be unreliable in commodities where the available hedge represents the value of the commodity for forward, rather than prompt, delivery. Considerable biases can arise when the time structure of prices is not considered, which tend to lead to overstatement of the efficiency of the hedging vehicle.

As an alternative we propose the use of simulations of hedges. The use of simulations not only produces very different results to standard financial formulae, but also demonstrates the sensitivity of the effectiveness of hedging to the time structure of prices. This produces some direct inferences for optimal hedging behaviour.

Our simulations consider how effective crude oil futures are for the hedging of various streams of tradeable crude oil. The futures contracts, used alone in a hedging strategy, are shown to perform unpredictably in the hedging of dated Brent, which is the direct price index for some 16 million barrels per day of crude oil trade, and whose influence, particularly in the Far East, is still expanding.

We contend that the reason for this poor hedging performance is the nonrandomness of the basis risk between futures and prompt crude oil. This basis tends to trend, and we consider hedging effectiveness in three regimes, contangos and both narrowing and widening backwardations. We find that the hedging effectiveness is highly dependent on the time structure regime. Because of the potential size and volatility of the basis, under some conditions using futures as a hedging instrument can produce more risk than unhedged positions. This also has implications for market structure, with the development of informal markets to help hedge the risk that can not be hedged by the use of the futures. The implication of our analysis is that the potential gains are considerable for futures market users who are unable, or unwilling, to access the subsidiary informal markets, should a futures contract whose value more closely proxies that of dated Brent be available.
\end{abstract}




\section{The Hedging Efficiency of Crude Oil Markets}

\section{Introduction}

The focus of this paper is on the measurement of hedging efficiency. We argue that conventional approaches, originally developed for analysing the hedging of Treasury bonds, are unreliable in commodities where the time structure of prices plays an important role. A full consideration of the nature and causes of changes in the time structure is necessary to develop an effective hedging strategy.

We consider the market for crude oil, which is prone to large variations in the time structure of prices. The results of simulations of actual hedges differ markedly from conventional efficiency measures which concentrate on variance reduction. This occurs because conventional measures overlook the basis risk inherent in the time structure of prices. Further, we note that there are considerable differences in efficiency between time structure regimes. There are differences not only between contangos and backwardations, but also between time periods when any backwardation is widening and when it is narrowing. Variations in the time structure can have a severely detrimental effect on the efficiency of the hedge.

The paper is divided into five sections. Section 2 considers the conventional method of hedge efficiency measurement based on price variances. Section 3 shows the results of simulated hedges in the market for UK North Sea Brent blend crude oil, and compares them to the conventional measure. Section 4 discusses how the time structure of crude oil prices leads to the relatively poor performance of simulated hedges compared to those implied by the variance measures. Section 5 extends the analysis to hedges involving the spread between Brent and other crude oils, and in particular the key US marker crude, West Texas Intermediate. Section 6 provides some conclusions and some implications for hedging strategy. 


\section{Variance Based Hedge Efficiencies}

The seminal approach to analysing hedging efficiency is that of Ederington (1979) ${ }^{1}$. His method can be summarised as follows : the potential hedger holds a portfolio, $P$, consisting of quantities $Q_{s}$ and $Q_{f}$ of spot and futures, with the respective variances of the prices of spot and futures being $\sigma_{s}^{2}$ and $\sigma_{f}^{2}$, and the covariance in prices being $\sigma_{\mathrm{s}}$.

Then $\operatorname{Var}(\mathrm{P})=\sigma_{\mathrm{s}}^{2} \mathrm{Q}_{\mathrm{s}}^{2}+\sigma_{\mathrm{f}}^{2} \mathrm{Q}_{\mathrm{f}}^{2}+2 \sigma_{\mathrm{sf}} \mathrm{Q}_{\mathrm{s}} \mathrm{Q}_{\mathrm{f}}$

Let $\theta$ be the proportion of the total holdings of the spot commodity that is hedged, so that $\theta=-Q_{\mathrm{f}} / \mathrm{Q}_{\mathrm{s}}$

Then $\operatorname{Var}(\mathrm{P})=\mathrm{Q}_{\mathrm{s}}^{2}\left(\sigma_{\mathrm{s}}^{2}+\theta^{2} \sigma_{\mathrm{f}}^{2}-2 \theta \sigma_{\mathrm{sf}}\right)$

The risk minimising hedge ratio will be that where $\partial \operatorname{Var}(\mathrm{P}) /-\partial \theta=0$

i.e. $\quad Q_{s}^{2}\left(2 \theta^{*} \sigma_{f}^{2}-2 \sigma_{s f}\right)=0$

and thus $\theta^{*}=\sigma_{\mathrm{sf}} / \sigma_{\mathrm{f}}^{2}$

Substituting this expression back into (1) gives the risk-minimising portfolio, $\mathrm{P}^{*}$, variance as

$$
\operatorname{Var}\left(\mathrm{P}^{*}\right)=\mathrm{Q}_{\mathrm{s}}^{2}\left(\sigma_{\mathrm{s}}^{2}-\sigma_{\mathrm{sf}}^{2} / \sigma_{\mathrm{f}}^{2}\right)
$$

The ratio of this variance to the variance of an unhedged portfolio is then:

$$
\mathrm{Q}_{\mathrm{s}}^{2}\left(\sigma_{\mathrm{s}}^{2}-\sigma_{\mathrm{sf}}^{2} / \sigma_{\mathrm{f}}^{2}\right) / \mathrm{Q}_{\mathrm{s}}^{2} \sigma_{\mathrm{s}}^{2}
$$

${ }^{1}$ Ederington, L.H. (1979), "The Hedging Performance of the New Futures Markets", Journal of Finance vol. 34 no. 1 .

O.I.E.S. 


$$
\begin{aligned}
& =1-\sigma_{\mathrm{sf}}^{2} / \sigma_{\mathrm{s}}^{2} \sigma_{\mathrm{f}}^{2} \\
& =1-\mathrm{r}^{2}
\end{aligned}
$$

Where $r^{2}$ is the population correlation coefficient between changes in price of the spot and future commodities.

Defining hedging efficiency as the proportional reduction in variance compared to an unhedged position then gives the hedge effectiveness, e, as being equal to $r^{2}$. Following the Ederington approach the correct hedge ratio, $\theta^{*}$, is given by $\sigma_{\mathrm{sf}}^{2} / \sigma_{\mathrm{f}}^{2}$, and the hedging efficiency will be given by $\theta^{*} \sigma_{\mathrm{s} f} / \sigma_{s}^{2}$.

There are major points that arise from the use of such an approach to analysing hedge efficiencies and constructing hedge ratios. The first is the problem that the approach concentrates on purely risk minimising agents which accept no trade off between risk and return. For example, in Figure $1 \mathrm{R}$ represents the risk -return frontier running between the portfolios $\mathrm{P}^{1}$ (unhedged, $\theta=0$ ), and $\mathrm{P}^{2}$ (fully hedged, $\theta=1$ ). $\mathrm{P}^{3}$ shows the riskminimising portfolio with $\theta=\theta^{*}$ as derived above. $\mathrm{P}^{3}$ cannot be utility-maximising as long as the agent will accept any trade off between risk and return. The utility-maximising point will be a point of tangency between $R$ and a risk-return indifference curve, such as the point $\mathrm{P}^{4}$ with $\theta<\theta^{*}$. Incorporation of utility maximisation rather than pure risk minimisation has been made in a series of empirical papers. ${ }^{2}$

The second major point is the correct form of estimation for e. With stationary data, the coefficient in the regression of $P_{s}$ and $P_{f}$ will equal $\theta^{*}$. Hedging efficiencies can be simply calculated as 1 minus the ratio of the variance of the basis to the variance of spot

${ }^{2}$ See in particular Cecchetti, S.G., E.E. Cumby and S. Figleski (1988), "Estimation of the Optimal Futures Hedge", Review of Economic Studies vol. 70. 
The Hedging Efficiency of Crude Oil Markets

\section{Expected \\ Return}

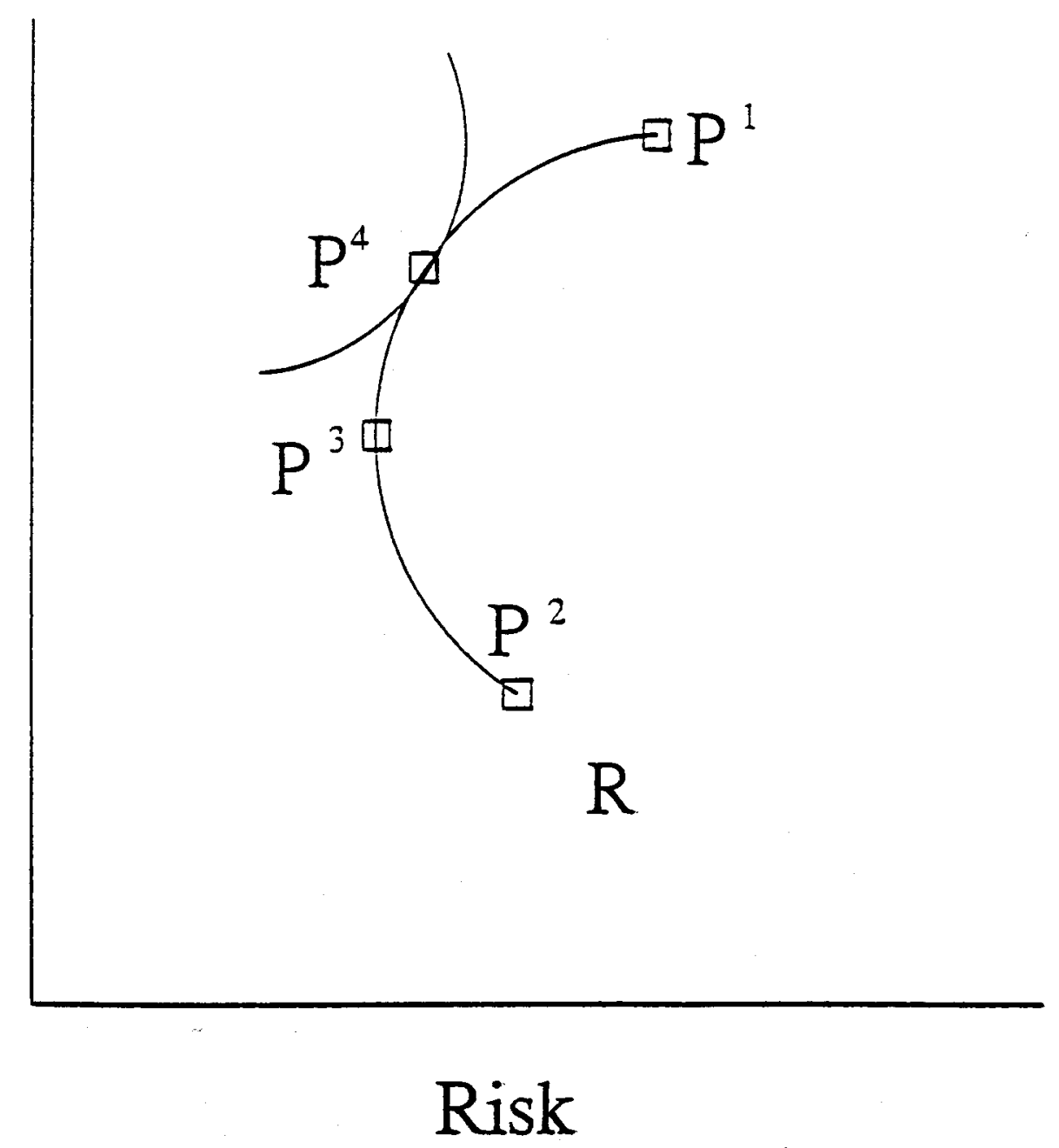

Figure 1 
prices. This empirical approach becomes inappropriate if the relationship between prices varies over time, if prices are non-stationary (i.e. do not have both constant means and variances), or if the variance of the basis is not normally distributed.

Several of the above cases have been dealt with in the literature. For instance, Cecchetti et al. $(1988)^{3}$ have considered the case where there is time variation in the joint distribution of $\left(\mathrm{P}_{\mathrm{s}}, \mathrm{P}_{\mathrm{t}}\right)$. Long $(1991)^{4}$, analysing gasoil futures, detected non-stationarity in prices, corrected by use of cointegration techniques, and revealed that such non-stationarity leads to severe biases in the standard measures of hedge ratios and hedging efficiencies.

This paper concentrates on a further departure from the standard assumptions and considers the consequences when the standard assumption of basis normality cannot be maintained. In particular, we consider the case where variance of the basis depends on the time structure of the market. Ederington's formula was based on the analysis of a financial market, namely the market for US T-Bonds. We find that variations of return due to any instability in the time structure of commodity markets can reduce the usefulness of the efficiency measure.

op. cit.

${ }^{4}$ D. Long (1991), European Gasoil Markets: Price Relationships, Hedging and Efficiency, WPM 16, Oxford Institute for Energy Studies, Oxford. 


\section{Simulations of Crude Oil Hedging}

In this section we consider the results of simulated hedges in the crude oil market as opposed to the use of financial formulae such as the Ederington measure explained in the previous section. We have used this methodology to show the results of actual hedges, and to quantify the benefits of hedging. We will show that while significant advantages can be gained by hedging, the Ederington formulae tends to overstate them. From the point of view of a real world hedger, reliance on the Ederington formula can result in unawareness of the true impact of their risk management operations.

For illustration all simulations are shown from the point of view of the short hedger. This is broadly representative of most risk management in the oil industry where, for example, a producer would hedge short term price risk arising from the sale of physical oil.

We provide the results of simulated hedges in the market for North Sea Brent blend. The essential features of this market, or in reality complex of markets, are as follows. Spot Brent, known as dated Brent, represents cargoes of half a million barrels of Brent blend to be loaded within fifteen days at the Sullom Voe terminal in the Shetland Islands. The market has two main hedging vehicles, an informal forward market and a futures contract at the International Petroleum Exchange of London (IPE), which is cash settled against forward market prices.

There are also a series of subsidiary Brent markets, of which the most important is the CFD (Contract for Differences) market, a hedging instrument which involves trading the spread between spot and forward prices for Brent. ${ }^{5}$ This is an informal swaps market with no centralised exchange or clearing house. We contend that this market has primarily arisen as a result of the deficiencies of futures contracts in hedging spot crude oil, and many major traders will use it as an adjunct to the futures market to improve hedging efficiency. The use of CFDs can be highly valuable in the risk management of companies

${ }^{5}$ An analysis of the markets for Brent is given in P. Horsnell and R. Mabro (1993), Oil Markets and Prices, Oxford University Press.

O.I.E.S. 
who trade this informal instrument. However, the market operates under regulatory and default risk, and has been prone to squeezes. As a result many hedgers who use the formal market are unwilling to use the informal market as an additional risk management mechanism.

For the purpose of this paper we will consider hedgers who are unwilling or unable to trade the CFD market. There is thus a proviso to our results, which will understate the hedging achievement of those who use both formal and informal instruments in constructing a hedge. Our focus here is purely on the effectiveness of the futures market alone, and not on several elements drawn from the complex of Brent markets being used simultaneously.

It should be noted that there is a very considerable amount of price risk linked to the Brent market. Its importance arises from the use of dated Brent as the marker for virtually all crude oil spot trade in Europe and West Africa. It is also used in the formula prices used in term sales to Europe and elsewhere by producer countries. In total as the price of dated Brent changes, the price of over one half of all world trade in crude oil (with a value of some $\$ 100$ billion per year) automatically changes by formula linkages.

The purpose of the paper is then to consider the effect of having futures contracts that converge onto the price of the forward rather than the spot commodity, in a world where the risk is primarily spot price related. We therefore consider the hedging of spot crude oil by the use of IPE futures Brent, and. as explained above, assume that no other instrument is used in conjunction with futures.

Our analysis in this and later sections covers several distinct time periods. We conducted separate analyses for the Gulf crisis (taken to be the period from the Iraqi invasion of Kuwait on 2nd August 1990 and the UN attack on Iraq on 16th January 1991), and for post crisis 1991. The simulated hedges were designed as follows. On each day we assume that a fresh hedge is opened, and have considered two cases according to whether 
the hedge was closed one or four weeks later. For each period the average profit or loss on the hedged position, and its mean deviation ${ }^{6}$, was calculated and compared to the profit or loss on the unhedged position.

We analysed prices for six types of crude oil to be hedged, with the results being shown in Table 1. For each simulation the average profit or loss for both hedged and unhedged positions is calculated together with their respective standard deviations. The mean deviations for unhedged and hedged positions are then calculated, and the hedging efficiency defined as the percentage reduction in the unhedged mean deviation brought about by hedging. The simulated hedges produce considerably less efficiency than the Ederington measure for all six crude oils and for both one and four-week hedges. The average efficiency of the simulations was 50 per cent for one-week hedges and 57.4 per cent for four-week hedges, compared to an average of 93.2 per cent for the Ederington measure. It is notable that the crude least effectively hedged by futures Brent is in fact dated Brent, the same crude oil differentiated only by its time of delivery. The bias is not being caused by crude oil quality or location, but by time as represented in the time structure of Brent prices.

The difference between simulated hedge efficiencies and the Ederington measure is demonstrated even more clearly by consideration of the Gulf crisis period as shown in Table 2. Here the average efficiency of the simulated one-week hedges is 46.7 per cent, and for the four-week hedges 36.9 per cent. The Ederington measure average is 91.8 per cent. The amount of risk left after hedging is highly significant in reality. While hedging reduces the losses from unhedged positions, more than half those losses remain and hence there will a role for further instruments such as CFDs. The Ederington measure by contrast implies that hedging removes virtually all risk, and leaves little value in the operation of any further hedging instrument beyond the futures contract.

\footnotetext{
${ }^{6}$ The mean plus 0.798 of a standard deviation.
} 
The Hedging Efficiency of Crude Oil Markets

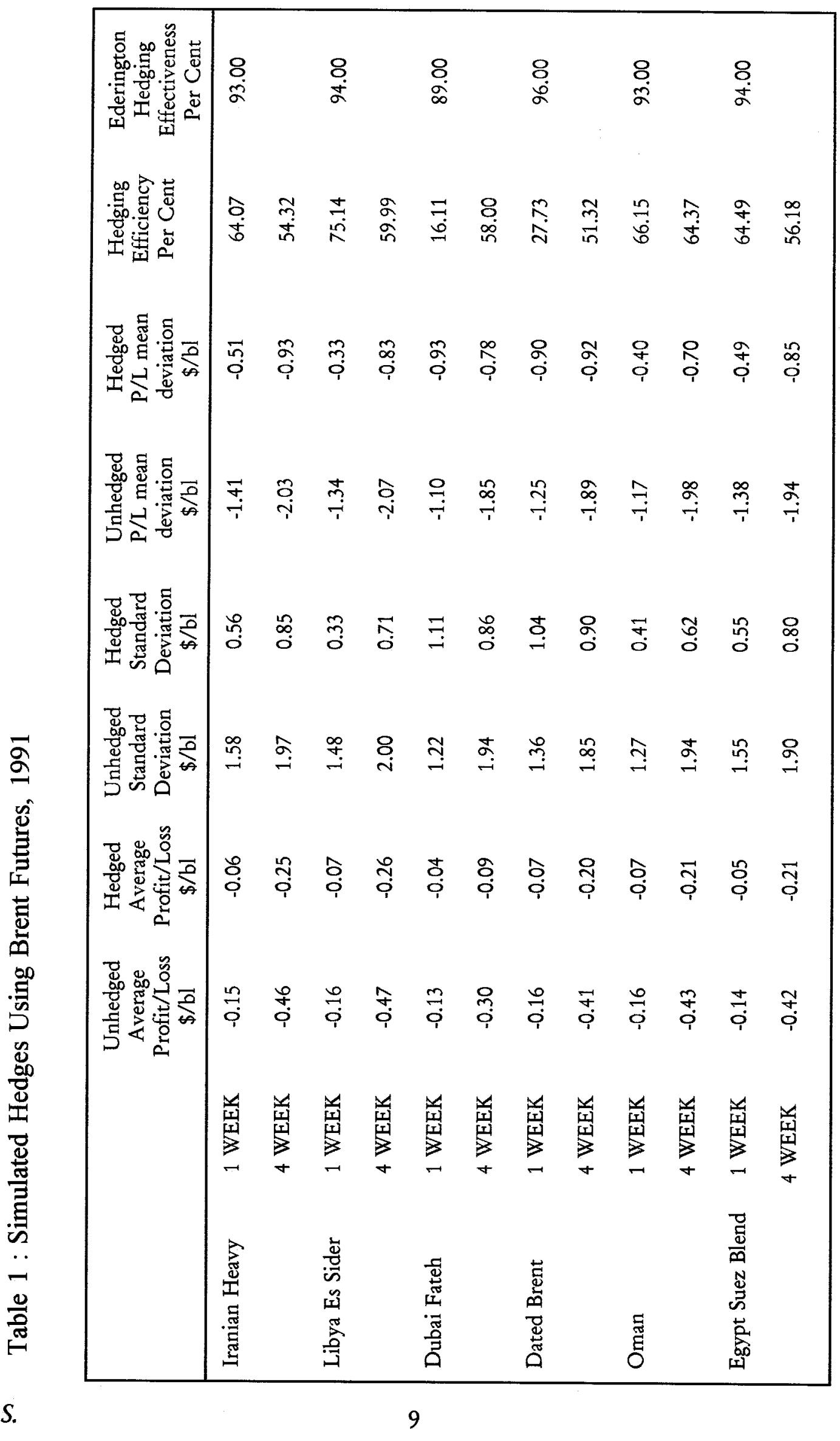


The Hedging Efficiency of Crude Oil Markets

\begin{tabular}{|c|c|c|c|c|c|c|c|c|c|c|c|c|}
\hline 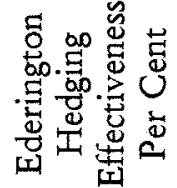 & $\frac{8}{\not{a}}$ & & $\begin{array}{l}8 \\
\text { ณू }\end{array}$ & & $\begin{array}{l}8 \\
\stackrel{8}{\infty}\end{array}$ & & $\begin{array}{l}8 \\
\text { ळ }\end{array}$ & & 용 & & $\begin{array}{l}8 \\
\text { 용 }\end{array}$ & \\
\hline 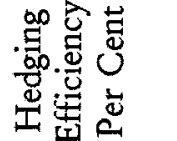 & $\begin{array}{l}R \\
\stackrel{R}{\sigma}\end{array}$ & 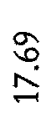 & $\begin{array}{l}\stackrel{\imath}{n} \\
\infty \\
\infty\end{array}$ & $\begin{array}{l}\stackrel{+}{\infty} \\
\stackrel{\nabla}{+}\end{array}$ & $\underset{\text { in }}{\stackrel{m}{i}}$ & $\begin{array}{l}\text { q } \\
\dot{m}\end{array}$ & $\frac{t}{5}$ & $\begin{array}{l}\stackrel{+}{\sigma} \\
\sigma \\
\sigma\end{array}$ & $\vec{m}$ & $\begin{array}{l}\text { ల. } \\
\infty \\
\infty\end{array}$ & $\begin{array}{l}\stackrel{\infty}{\vec{p}} \\
\stackrel{p}{+}\end{array}$ & 吕 \\
\hline 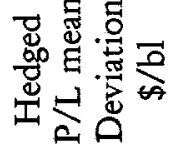 & ָ̊ & గొ & $\stackrel{\infty}{\rightarrow}$ & 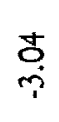 & $\stackrel{\infty}{\rightarrow}$ & $\begin{array}{l}\stackrel{+}{\infty} \\
\text { ণ }\end{array}$ & $\stackrel{n}{7}$ & $\stackrel{f}{\sim}$ & $\stackrel{m}{\rightarrow}$ & $\begin{array}{l}8 \\
\infty \\
i\end{array}$ & 咢 & 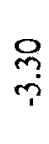 \\
\hline 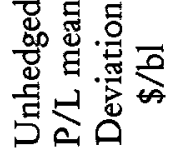 & $\stackrel{\text { ก̂ }}{\text { กิ }}$ & $\stackrel{m}{+}$ & $\begin{array}{l}\stackrel{n}{\infty} \\
\sim \\
i\end{array}$ & 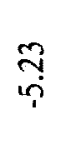 & $\stackrel{\text { r্}}{\sim}$ & $\stackrel{m}{\dot{t}}$ & $\underset{\sim}{\stackrel{T}{*}}$ & \begin{tabular}{l}
$\mathscr{0}$ \\
\multirow{t}{*}{}
\end{tabular} & $\begin{array}{l}\text { Tै } \\
\text { ָ̦ }\end{array}$ & $\stackrel{n}{\dddot{n}}$ & $\begin{array}{l}\vec{\infty} \\
\vec{\gamma}\end{array}$ & $\begin{array}{l}\text { fे } \\
\text { 它 }\end{array}$ \\
\hline 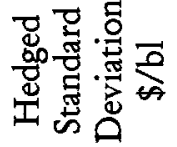 & $\stackrel{\leftrightarrow}{و}$ & $\stackrel{\infty}{\rightarrow}$ & $\stackrel{\text { ô }}{\circ}$ & $\stackrel{\infty}{\stackrel{\infty}{-}}$ & ن. & $\stackrel{ \pm}{\stackrel{I}{-}}$ & $\underline{\text { on }}$ & $\stackrel{\overbrace{}}{\sim}$ & ્ָ & $\stackrel{m}{\rightarrow}$ & $\stackrel{\overbrace{}}{\rightarrow}$ & $\underset{\sim}{ت}$ \\
\hline 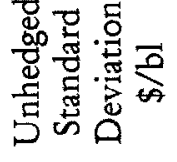 & $\stackrel{m}{m}$ & in & 悉 & 음 & ઼ָ & 음 & nn & $\stackrel{m}{\sigma}$ & $\stackrel{\vec{m}}{m}$ & is & $\underset{\tilde{b}}{\tilde{m}}$ & ?ొ \\
\hline 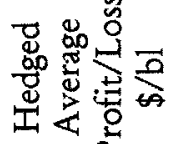 & f̊ & $\underset{\text { ì }}{\text { i }}$ & $\vec{m}$ & $\stackrel{\text { +o }}{\rightarrow}$ & 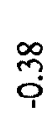 & $\stackrel{10}{\stackrel{2}{\longrightarrow}}$ & $\stackrel{m}{i}$ & $\stackrel{\text { mె }}{\rightarrow}$ & के & $\stackrel{+}{\stackrel{+}{+}}$ & $\stackrel{\text { m? }}{i}$ & 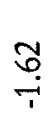 \\
\hline 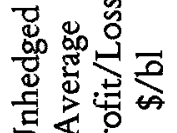 & $\stackrel{2}{2}$ & $\stackrel{\text { }}{\stackrel{i}{i}}$ & ợ & ণ্ণ & ్ㅗㅇ & ণั & $\vec{z}$ & $\stackrel{m}{9}$ & ồ & $\vec{n}$ & 웅 & ণ़े \\
\hline & 凷 & $\begin{array}{l}\text { y } \\
\text { 昰 } \\
+\end{array}$ & 凷 & $\begin{array}{l}4 \\
y \\
+\end{array}$ & 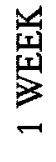 & $\begin{array}{l}4 \\
4 \\
4 \\
4 \\
4\end{array}$ & 荘 & $\begin{array}{l}4 \\
y \\
y \\
+1 \\
+\end{array}$ & 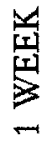 & $\begin{array}{l}4 \\
4 \\
+4 \\
+4 \\
+4\end{array}$ & 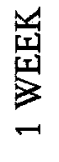 & $\begin{array}{l}y \\
\text { 密 } \\
\vdots \\
+\end{array}$ \\
\hline & 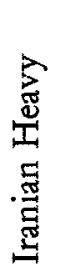 & & 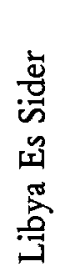 & & 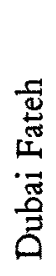 & & 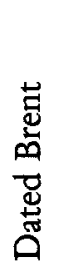 & & 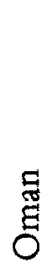 & & 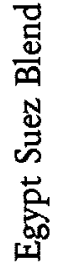 & \\
\hline
\end{tabular}


The measure of hedge efficiency based on comparison of average profit or losses from hedged and unhedged positions we have used, is, we would argue, of more relevance to the real world hedger than the Ederington measure which is based purely on price variances. Including the variations in return arising from the time structure of prices provides a better picture of the impact on the overall financial costs and benefits of hedging operations.

The Ederington formula was designed for use in financial futures. It does not perform well in some commodity markets, and especially crude oil markets, despite its prevalent use. The reason lies in the presence of often large and unstable contangos and backwardations in crude oil markets. The backwardations tend to be larger than in other commodity markets, and they tend to have greater duration. To fully assess hedging effectiveness in crude oil markets further consideration has to be given to these features. 


\section{The Time Structure of Crude Oil Prices}

Crude oil markets have a tendency to be in backwardation. This feature arises more from refiners' behaviour and from the logistics of crude oil supply, than from any form of 'normal backwardation' as propounded by Keynes and Hicks'. Crude oil is a bulky commodity for which storage is expensive and limited. There is a strong incentive for refiners to keep close to minimum inventory levels. Compared to metals or to agricultural commodities there is less demand (in terms of days of forward demand) for precautionary inventories. In addition, oil has a very different mode of operation compared to metals or to soft commodities. In the metals market, incremental production tends to be only a small fraction of total available stocks. The time structure of soft commodity prices and the swings between backwardations and contangos are determined completely by harvest times. Backwardations in oil are a function of the supply-demand balance for promptly delivered crude oil. Tightness in the short-term market results in a backwardation, the premium for prompt delivery. By contrast, a contango normally arises where the prompt market is well supplied. If the contango grows large enough to cover interest and storage charges, then it will encourage stockbuilding, which tends to stabilise and prolong the period of contango.

A few key points need to be made about the asymmetry of the characteristics of contangos and backwardations in the crude oil market. First, there is an asymmetry in their potential size. The size of a contango is limited by the storage cost of oil (at least while spare storage capacity remains). Cash-and-carry arbitrage (buying prompt, storing and selling forward) keeps the contango within bounds. By contrast, there is no necessary limit to the size of a backwardation. As a backwardation is a premium that refiners are willing to pay for prompt delivery, its maximum is undefined in extremely tight prompt markets. The second asymmetry concerns stability. Backwardations tend to be unstable, and can either widen or narrow quickly. By contrast, contangos tend to be stable.

${ }^{7}$ J.M. Keynes (1930) A Treatise on Money vol. 2, J.R. Hicks (1946) Value and Capital, Oxford University Press.

O.I.E.S. 
The basis variance tends not be a random day to day change. It often (and indeed generally) exhibits a systematic trend. In particular backwardations will tend to narrow or widen systematically, often over a considerable period of time in relation to the time horizon of most real world oil hedging operations.

Figures 2 and 3 show two examples of this effect. In Figure 2 a narrowing backwardation between dated Brent and the January 1993 IPE Brent contract is shown with a typical trend in the narrowing of the basis. In Figure 3 a widening backwardation between dated Brent and the March 1993 IPE Brent contract is shown. These figures are illustrative of the general phenomenon that backwardations in oil do systematically narrow or widen. The hypothesis of serial independence in the change in the basis during periods of backwardation can be rejected, i.e. statistically there is no random walk in the level of crude oil backwardations.

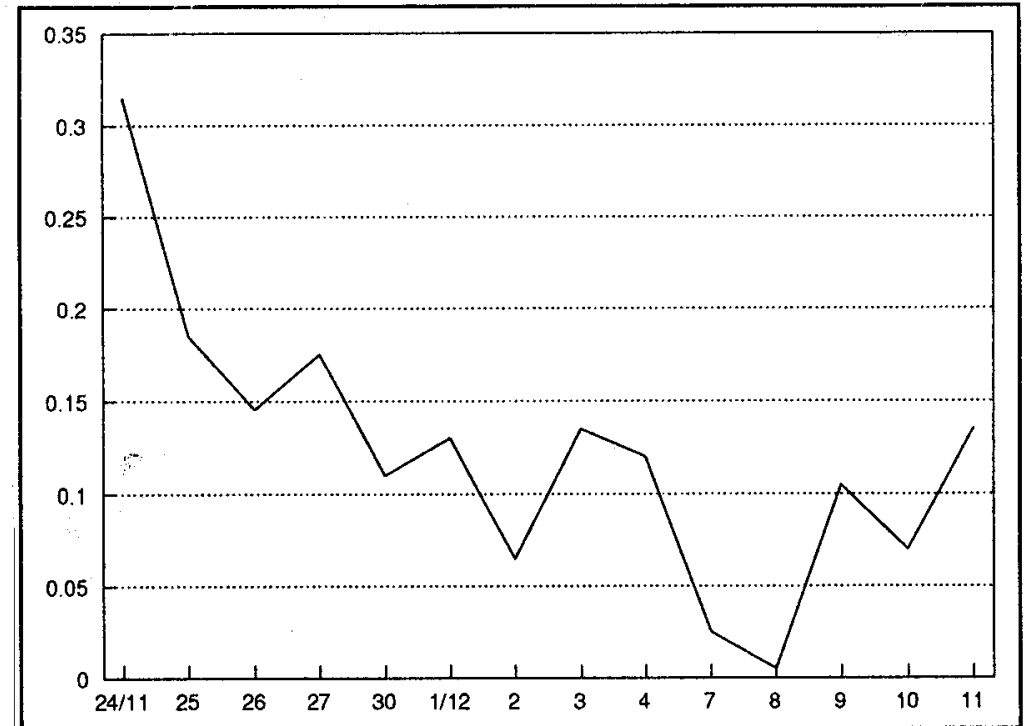

Figure 2 : Brent Backwardation (Narrowing). Dated Brent minus IPE Brent January 1993 contract. November 24th to December 11th 1992. \$ per barrel. 


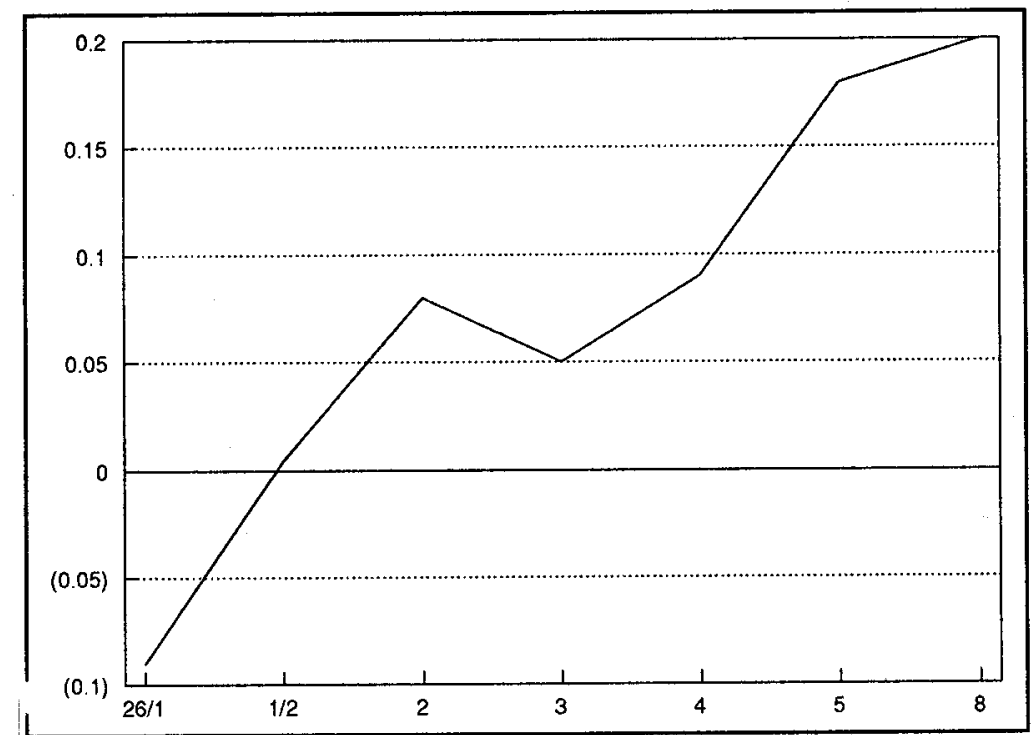

Figure 3 : Brent Backwardation (Widening). Dated Brent minus IPE Brent March 1993 contract. January 28th to February 8th 1993. \$ per barrel.

A backwardation represents an unfavourable bias to the short hedger. If the backwardation widens then the bias increases, reducing the attractiveness of hedging. A combination of widening backwardations together with increases in prompt prices should militate against the opening of any short hedges. The simulations demonstrate this clearly, while the effect is lost when using the Ederington formula.

The impact of changes in the time structure of prices is of crucial importance. In Table 3 the Gulf crisis period is broken into two sub-periods, one manifesting narrowing, and one widening backwardations. As there was no contango during the Gulf crisis given the demand pressure on prompt supplies, the 1992/3 period is used to show contangos. The efficiencies of the simulated hedges of dated Brent by Brent futures are shown, together with the Ederington formula efficiencies. 


\begin{tabular}{|c|c|c|c|}
\hline \multicolumn{4}{|c|}{ Table 3 : Hedging Effectiveness by Time Structure of Prices } \\
\hline & Narrowing & Widening & Contango \\
\hline & Backwardation & Backwarda & \\
\hline \multicolumn{4}{|c|}{ Ederington Formula } \\
\hline 1 week & $87 \%$ & $91 \%$ & $82 \%$ \\
\hline 4 week & $95 \%$ & $95 \%$ & $87 \%$ \\
\hline \multicolumn{4}{|c|}{ Simulated Hedges } \\
\hline 1 week & $65 \%$ & $-1350 \%$ & $68 \%$ \\
\hline 4 week & $57 \%$ & $-9 \%$ & $86 \%$ \\
\hline
\end{tabular}

The result of simulated hedges presented in Table 3, shows that widening backwardations pose particular problems for short hedgers, representing an increase in the bias against the hedger. Under conditions of widening backwardations, the simulated hedges have negative efficiency, i.e. hedging under these circumstances simply adds to the effect of holding an unhedged position. Short hedges should not normally be opened under conditions of widening backwardations and rising prices. By contrast, the Ederington formula implies that hedging is highly effective under these circumstances. The differences between the regimes also imply that an analysis based on, say, daily data over the course of a year can be misleading. ${ }^{8}$ Such an analysis will combine periods of contango, where the simulations imply that hedging is highly effective, together with the two backwardation regimes where it is not.

${ }^{8}$ See for example K.M. Dominguez (1989) "The Volatility and Efficiency of Crude Oil Futures Contracts" in K.M. Dominguez et. al. Oil and Money: Coping with Price Risk Through Financial Markets, Harvard University Press.

O.I.E.S. 


\section{Using Other Crude Oil Futures}

The time structure of crude oil prices is essentially a regional phenomenon dictated by local supply-and-demand factors. There is no reason why the time structure of North Sea prices should necessarily be similar to those in the USA. The price of the US domestic marker crude oil, West Texas Intermediate (WTI), is determined by the trading of the light sweet crude oil contract on the New York Mercantile Exchange (NYMEX). The NYMEX contract is based on delivery at Cushing Oklahoma, from whence crude oil can only flow north by pipelines into the Mid-West. Thus, the supply-demand balance relevant for WTI is that of the Mid-West region, in particular, Indiana, Illinois and Kentucky (the I-I-K refining district).

Potential biases are larger when we consider the hedging of positions involving a spread between Brent and other marker crude oils, particularly in the US market. Distortions due to differential movements in the time structure of prices affect the basis risk between Brent and crude oils in other regions of the world. The markets for Brent and WTI need not be in contango or backwardation at the same time, and frequently are not, because of the dissimilarities between patterns in I-I-K and the North Sea.

A major part of this difference is logistical. As it is a pipeline market, the market for WTI is prone to the effects of pipeline scheduling, which must be completed by the 24th of the month prior to delivery. At times of peak demand, pipeline space becomes scarce, and near-month deliveries are bid up, resulting in large backwardations. This effect is often known as the "Cushing cushion", and represents a decoupling of WTI prices from the world market. When the cushion is in operation, large backwardations in WTI can occur even when other world markets are in contangos. The characteristics of US MidWest supply problems are usually unrelated to the supply situation in other areas.

A second cause of the difference relates to the timing of peak demand. Outside the USA, this tends to occur in the winter, with a peak demand for distillate products. The time structures of prices in the WTI and Brent markets tend not to move together, and indeed any correlation could be negative. In the I-I-K refining area, peak demand occurs 
during the late Spring to early Autumn seasonal peak for gasoline demand. Thus the most likely time for backwardations in the WTI market is, in fact, the most likely time for contangos in the Brent market. Furthermore, the basis between Brent and WTI exhibits long periods of systematic trending. Figure 4 shows the behaviour of the June 1994 WTI contract to Dated Brent differential from January 1994 until the expiry of the WTI contract at the end of May. A series of pronounced trends are apparent, with systematic widenings and narrowings of the differential that trend, often for periods of a month or more.

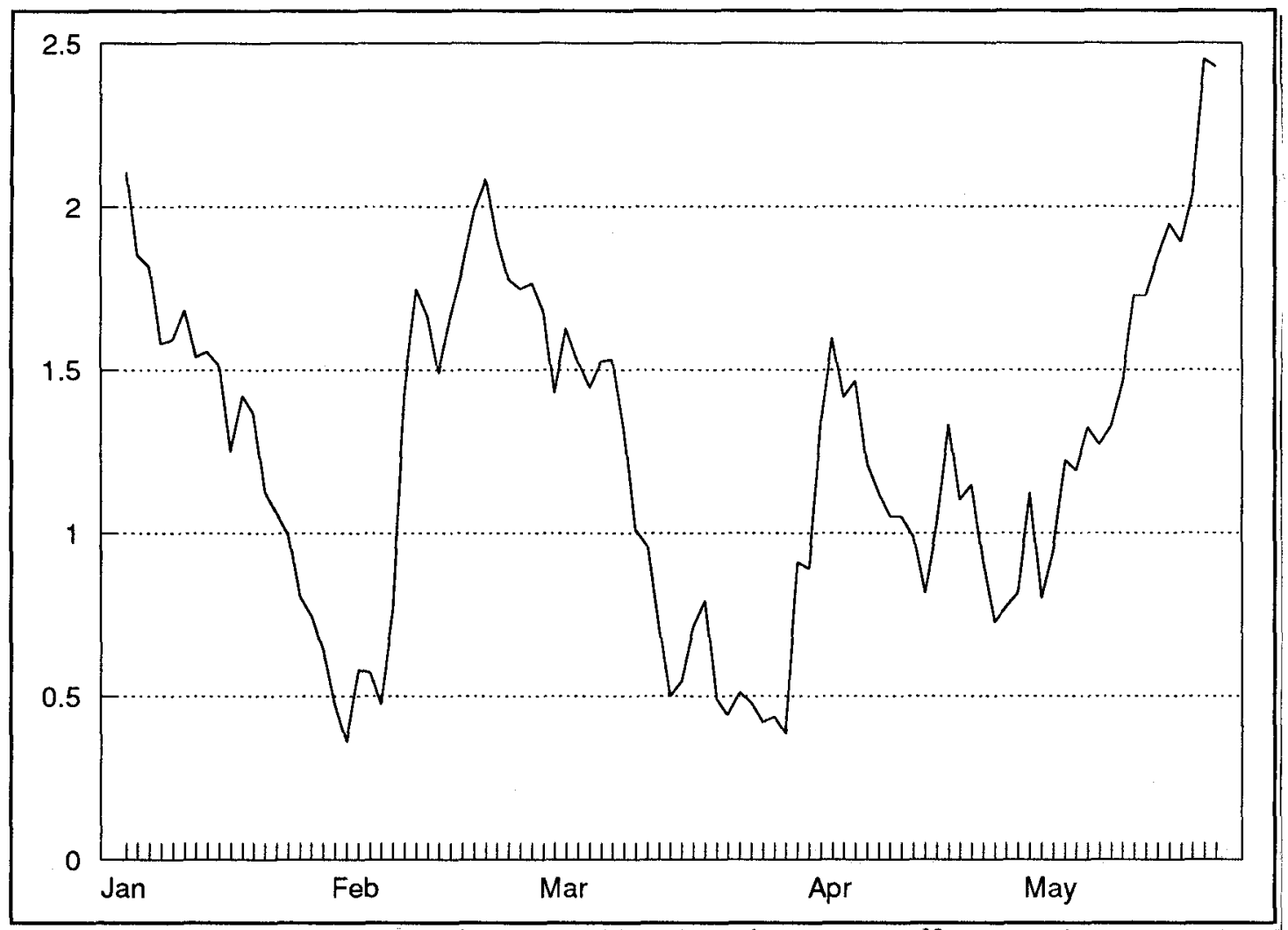

Figure 4: West Texas Intermediate - Dated Brent Differential. June 1994 NYMEX WTI contract minus Dated Brent, January to May 1994. \$ per barrel.

For purposes of comparison, the analysis of the effectiveness of Brent futures shown in Tables 1 and 2 is repeated using WTI futures as the risk-management instrument in Tables 4 and 5. Two main points emerge from these tables. First, the overstatement of O.I.E.S. 
during the late Spring to early Autumn seasonal peak for gasoline demand. Thus the most likely time for backwardations in the WTI market is, in fact, the most likely time for contangos in the Brent market. Furthermore, the basis between Brent and WTI exhibits long periods of systematic trending. Figure 4 shows the behaviour of the June 1994 WTI contract to Dated Brent differential from January 1994 until the expiry of the WTI contract at the end of May. A series of pronounced trends are apparent, with systematic widenings and narrowings of the differential that trend, often for periods of a month or more.

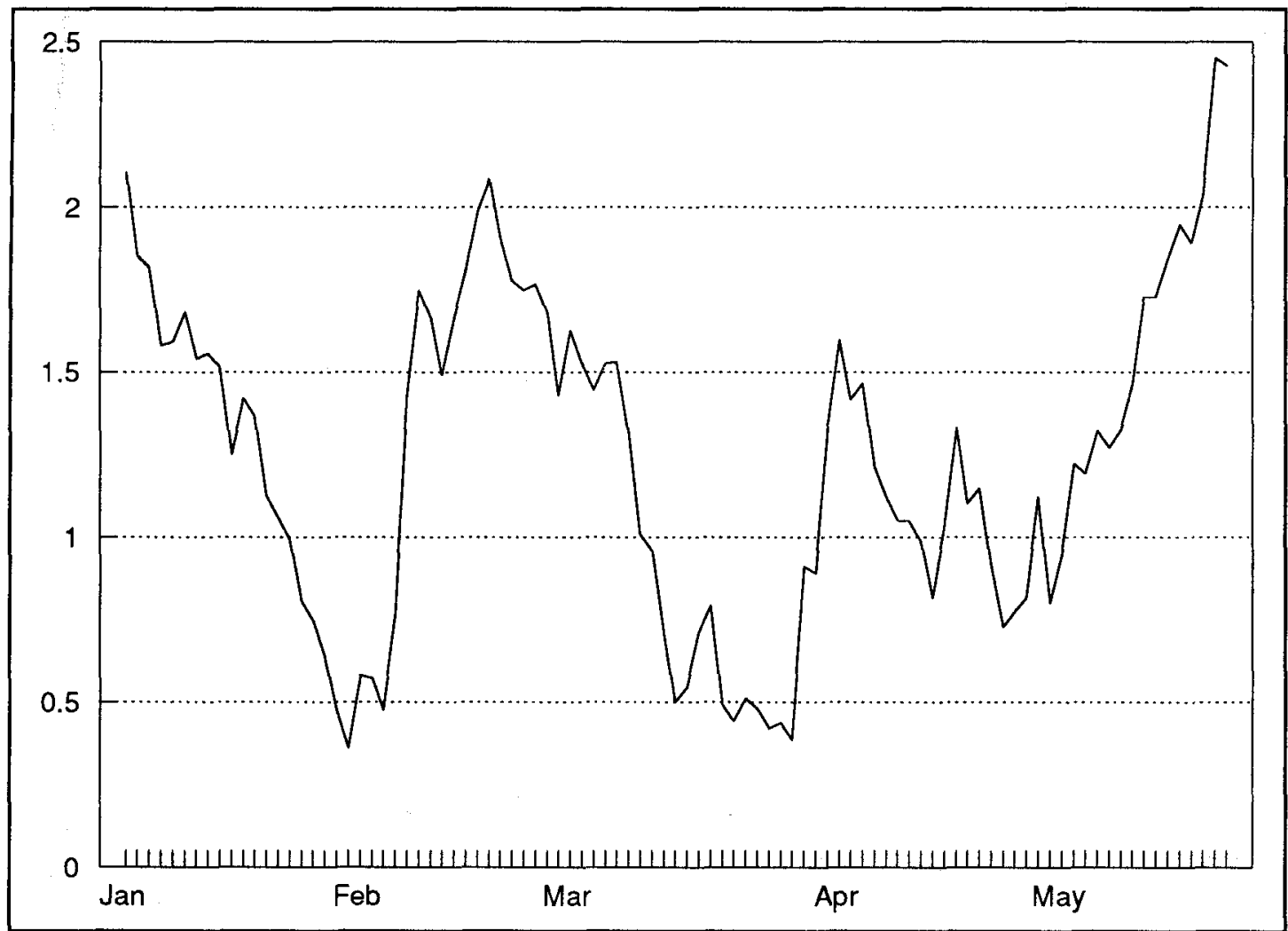

Figure 4 : West Texas Intermediate - Dated Brent Differential. June 1994 NYMEX WTI contract minus Dated Brent, January to May 1994. \$ per barrel.

For purposes of comparison, the analysis of the effectiveness of Brent futures shown in Tables 1 and 2 is repeated using WTI futures as the risk-management instrument in Tables 4 and 5. Two main points emerge from these tables. First, the overstatement of O.I.E.S. 
efficiency by the Ederington measure in crude oil markets is confirmed. It is not confined to hedging using Brent. Secondly, while IPE Brent futures do provide a better instrument for the six crude oils than do NYMEX WTI futures, the differential in performance is not as large as that implied by the Ederington formula, which captures the basis risk between WTI and Brent while missing the dominant time risk. 
The Hedging Efficiency of Crude Oil Markets

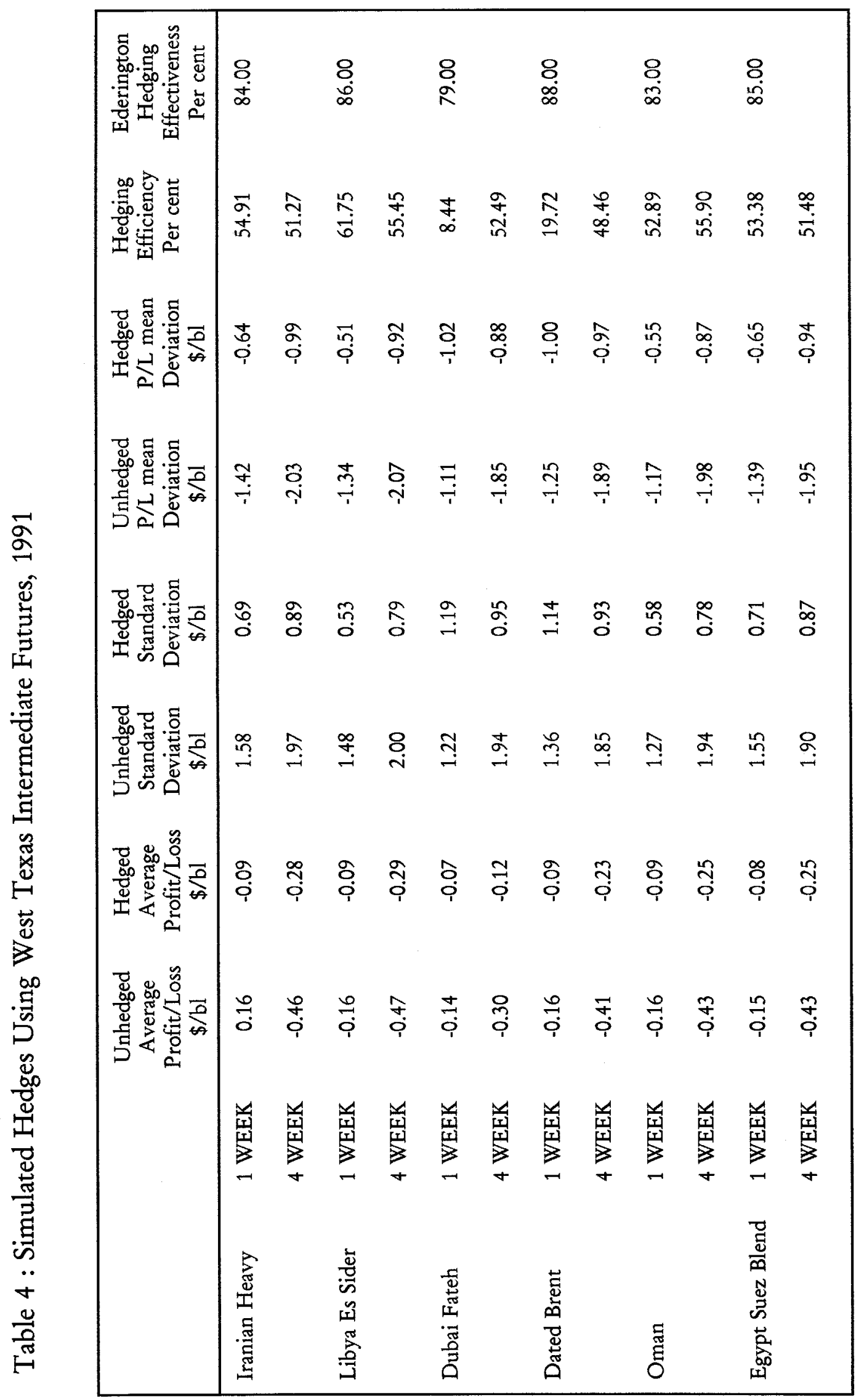

O.I.E.S. 
The Hedging Efficiency of Crude Oil Markets

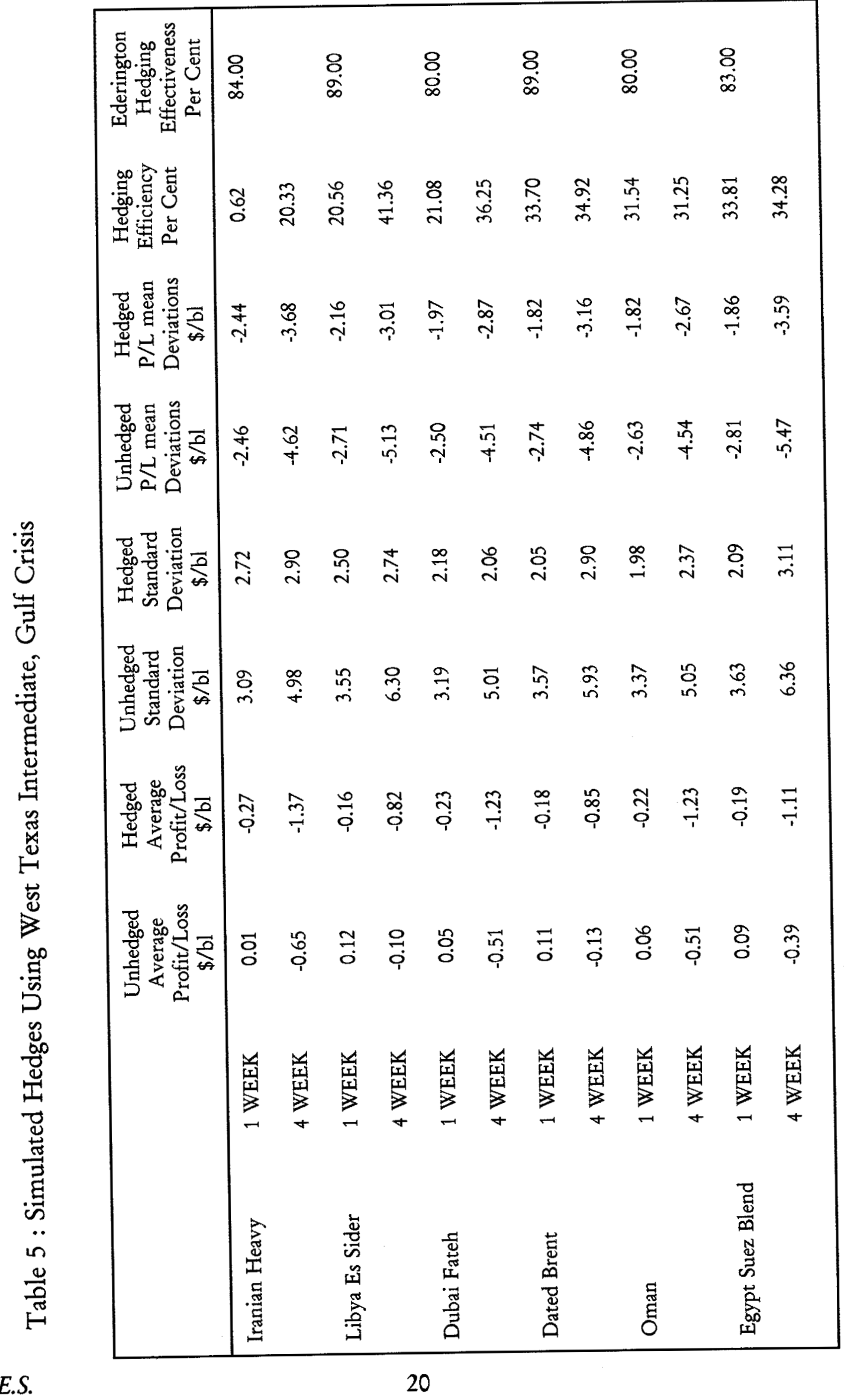




\section{Conclusions}

We have considered the problems of hedging a commodity where movements in basis risk can show systematic trends. In particular, we have shown that hedging performance in the crude oil market is dependent on the time structure of prices, and that contangos and narrowing and widening backwardations represent three distinct regimes. Variance reduction measures of hedging efficiency, which conflate all three regimes and assume random behaviour of the basis risk, tend to overestimate efficiency in comparison with the results of simulated hedges. We have demonstrated that simulation produces a more meaningful measure.

We have seen that, while less than that implied by variance reduction measures, hedging in crude oil markets produces very significant reductions in risk. There is some significant residual risk which arises from the need to hedge spot commodities with a hedging instrument that represents oil for forward delivery and that does not converge on spot prices.

The clear conclusion of our analysis is that hedgers do need to take account of the time structure, and consider and take a view of its dynamics. The inferences that can be drawn on the likely effectiveness of hedging crude oil using futures alone are summarised in Table 6 for both short and long hedgers. 


\begin{tabular}{|c|c|c|}
\hline Time Structure & Short Hedge & Long Hedge \\
\hline Narrowing Backwardation & Medium & Medium \\
\hline Widening Backwardation & Low & High \\
\hline Contango & High & $\begin{array}{c}\text { Medium } \\
\text { and Limited }\end{array}$ \\
\hline
\end{tabular}

The effectiveness of hedging is lowest when the time structure is moving against the hedger, e.g. for a short hedger in a widening backwardation. Hedging strategy is therefore vitally dependent on the current time structure of prices, and also requires a view to be taken over its future evolution. To achieve this a successful hedging strategy must take in account the reasons why, say, a backwardation is changing.

If hedging using Brent futures leaves considerable time risk, the question is then raised as to the potential value of a futures contract that reflected the value of dated Brent and thus removed that time risk. We have considered hedging crude oil from the point of view of the hedger who only uses futures as a risk management instrument. We have noted that many market participants also use informal mechanisms, in particular CFDs, toimprove hedging performance. 
OXFORD INSTITUTE FOR ENERGY STUDIES

57 WOODSTOCK ROAD, OXFORD OX2 6FA ENGLAND

TELEPHONE (01865) 311377

FAX (01865) 310527

E-mail: publications@oxfordenergy.org

http://www.oxfordenergy.org 